\title{
7 Apprenticeships with and without Guilds: The Northern Netherlands
}

\section{Ruben Schalk}

After the Dutch Revolt, the Northern Netherlands entered a phase of dynamic economic growth that lasted until the middle of the seventeenth century. ${ }^{1}$ Although the eighteenth century was marked by protracted stagnation, the Dutch economy remained relatively advanced. ${ }^{2}$ It would take until the last quarter of the nineteenth century for industrialisation to take off. ${ }^{3}$ These developments make Dutch apprenticeship all the more interesting. Relatively efficient labour markets and a large stock of human capital are often regarded as indispensable for economic development, while closed labour and training markets are supposed to have been detrimental. ${ }^{4}$ Apprenticeship took centre stage in both skill formation and labour-market access for adolescents in the Dutch Republic. How difficult was it for a Dutch youngster to become a skilled artisan during the various stages of the country's economic development?

Historians' views on apprenticeship in the Netherlands vary widely. Ogilvie has argued that the early modern Northern Netherlands had relatively weak craft guilds, allowing youngsters easy access to training. ${ }^{5}$ Van Zanden, in contrast, suggests that guilds' regulation of apprenticeship

${ }^{1}$ O. Gelderblom and J. Jonker, 'Low Countries', in: L. Neal and J. G. Williamson (eds.), The Cambridge History of Capitalism, vol. 1: The Rise of Capitalism: From Ancient Origins to 1848 (Cambridge: Cambridge University Press, 2015), 314-56.

2 J. de Vries and A. van der Woude, The First Modern Economy: Success, Failure, and Perseverance of the Dutch Economy, 1500-1815 (Cambridge: Cambridge University Press, 1997).

${ }^{3}$ J. L. van Zanden and A. van Riel, The Strictures of Inheritance: The Dutch Economy in the Nineteenth Century (Princeton: Princeton University Press, 2004); J. Mokyr, 'The Industrial Revolution and the Netherlands: Why did it not happen?', De Economist 148 (2000), 503-20.

${ }^{4}$ J. Mokyr, The Enlightened Economy: An Economic History of Britain 1700-1850 (New Haven, CT: Yale University Press, 2012); P. H. Lindert, Growing Public: Social Spending and Economic Growth since the Eighteenth Century (Cambridge: Cambridge University Press, 2004); S. Ogilvie, 'The economics of guilds', Fournal of Economic Perspectives 28 (2014), 169-92.

5 S. Ogilvie, State Corporatism and Proto-Industry: The Württemberg Black Forest, 1580-1797 (Cambridge: Cambridge University Press, 1997), 436-37, 449. 
instead enabled a relatively cheap supply of skilled workers. ${ }^{6}$ De Vries presents a third position, that access to skilled labour markets became more difficult during the eighteenth century because guilds closed their ranks. ${ }^{7}$ What happened to apprenticeship after the guilds were abolished and industrialisation set in largely remains an open question, although Knotter has suggested that industrialisation caused deskilling and segmentation in the Amsterdam labour market during the nineteenth century. ${ }^{8}$

This chapter provides a systematic study of Dutch apprenticeship between the seventeenth and nineteenth centuries. We begin by examining craft apprenticeship under the guilds in several different cities. Although apprenticeship was not confined to guild-controlled crafts in the Northern Netherlands, evidence for training outside the guilds is scarce. ${ }^{9}$ As the vast majority of urban crafts were organised in guilds, these apprenticeships were arguably the most significant form of training. Even within this setting, apprenticeship contracts were private agreements between masters and youths, with little direct guild involvement. This implies that we can capture both the institutional and private dimensions of Dutch apprenticeship - as we show, pre-industrial apprenticeship training was remarkably similar across the Dutch Republic. We then move on to the nineteenth century, to examine what happened to apprenticeship after guilds had been abolished and industrialisation set in.

\section{Apprenticeship in the Dutch Republic}

Apprenticeship in the Northern Netherlands grew in tandem with the rise of urbanisation in the sixteenth century, most notably in Holland and

${ }^{6}$ J. L. van Zanden, 'The skill premium and the "Great Divergence”, European Review of Economic History 13 (2009), 139-40.

${ }^{7}$ J. de Vries, 'How did pre-industrial labour markets function?', in: G. Grantham and M. MacKinnen (eds.), Labour Market Evolution: The Economic History of Wage Flexibility and the Employment Relations (London: Routledge, 1994), 39-63.

${ }^{8}$ A. Knotter, Economische transformatie en stedelijke arbeidsmarkt: Amsterdam in de tweede helft van de negentiende eeuw (Zwolle: Waanders, 1991).

${ }^{9}$ For apprenticeships outside craft guilds see C. A. Davids, 'Apprenticeship and guild control in the Netherlands, c. 1450-1800', in: B. De Munck, S. L. Kaplan and H. Soly (eds.), Learning on the Shop Floor: Historical Perspectives on Apprenticeship (New York: Berghahn Books, 2007), 65-84; N. W. Posthumus, Geschiedenis van de Leidse lakenindustrie, 3 vols. (The Hague: Nijhoff, 1908-39). Dutch municipal orphanages registered apprenticeships of their orphans, but they were also regularly apprenticed at guildcontrolled crafts; A. E. C. McCants, Civic Charity in a Golden Age: Orphan Care in Early Modern Amsterdam (Urbana: University of Illinois Press, 1997); R. Schalk, 'From orphan to artisan: Apprenticeship careers and contract enforcement in the Netherlands before and after the guild abolition', Economic History Review 70 (2017), 730-57. 
Zeeland. ${ }^{10}$ It had probably been used since the late Middle Ages. Since one prerequisite for establishing a craft guild was a certain concentration of artisans, apprenticeship probably coincided with or preceded their establishment. ${ }^{11}$ Apprenticeship here was first and foremost a local and urban institution. The decentralised structure of the Dutch Republic was mirrored in the composition of Dutch apprenticeship in the early modern period. ${ }^{12}$ Apprenticeship was not regulated at the national or provincial level. At the urban level, craft guilds were often involved, as was true for many cities in early modern Europe.

Guild involvement with apprenticeship usually consisted of four features: registering apprentices, setting the duration, charging fees and sometimes limiting the number of apprentices per master. ${ }^{13}$ Guilds also specified the rules for the test and fee that prospective master's faced on entering the guild. Only those who passed a mastership test could become guild members. Journeymen and apprentices were not formally guild members, and to become a journeyman, a completed apprenticeship was required. The apprentice's service was usually attested by their master in person, or else documented in a letter from their master if they had trained in a different town or city.

Dutch guilds appear to have been more concerned with registering this process than actually overseeing it. ${ }^{14}$ Most guilds kept records of new apprentices, journeymen and masters, especially for immigrants. They did also make rules for minimum terms, demand fees and sometimes limited the number of apprentices. Fees and terms were far from uniform, however, both between cities and between guilds. ${ }^{15}$ Cooper's apprentices in Haarlem had to serve for twice as long as their peers in Rotterdam at the end of the seventeenth century, for example. ${ }^{16}$ Guilds' involvement rarely extended beyond these limited procedural issues.

${ }^{10}$ B. De Munck, P. Lourens and J. Lucassen, 'The establishment and distribution of craft guilds in the Low Countries, 1000-1800', in: M. Prak, C. Lis, J. Lucassen and H. Soly (eds.), Craft Guilds in the Early Modern Low Countries: Work, Power, and Representation (Aldershot: Ashgate, 2006), 32-73.

${ }^{11}$ Fifteenth-century guild ordinances for instance already contained clauses on apprenticeship fees; P. Lourens and J. Lucassen, 'De oprichting en ontwikkeling van ambachtsgilden in Nederland (13de-19de eeuw)', in: C. Lis and H. Soly (eds.), Werelden van verschil: Ambachtsgilden in de Lage Landen (Brussels: VUB Press, 1997), 50-51; B. De Munck and K. Davids, 'Beyond exclusivism: Entrance fees for guilds in the early modern Low Countries, c. 1450-1800', in: K. Davids and B. De Munck (eds.), Innovation and Creativity in Late Medieval and Early Modern European Cities (Farnham: Ashgate, 2014), 213-14.

12 O. C. Gelderblom, Cities of Commerce: The Institutional Foundations of International Trade in the Low Countries, 1250-1650 (Princeton: Princeton University Press, 2013).

${ }^{13}$ Davids, 'Apprenticeship and guild control', $67 .{ }^{14}$ Ibid.

${ }^{15}$ De Munck and Davids, 'Beyond exclusivism'.

${ }^{16} \mathrm{~J}$. Tump, 'Ambachtelijk geschoold: Haarlemse en Rotterdamse ambachtslieden en de circulatie van technische kennis, ca. 1400-1720', PhD thesis, VU Amsterdam, 2012, 88. 
The vast majority of urban crafts in the Dutch Republic were incorporated into guilds, meaning that apprenticeships in urban crafts were generally registered by guilds as well. Davids has nevertheless demonstrated that another (albeit unknown) share of apprentices worked outside the guild system. ${ }^{17}$ Textile manufacturing, watchmaking and millwrights in the Zaanstreek, for instance, were not organised in guilds. ${ }^{18}$ Guilds were rare in small towns with fewer than 1,000 inhabitants, so here too apprenticeships were not monitored. ${ }^{19}$ Even within towns, some guilds were more involved with apprenticeship than others. Guilds of merchants, shopkeepers and bargemen generally did not regulate apprenticeships.

Historians have struggled to examine apprenticeship outside of guilds because it left so little evidence. Notaries rarely registered apprenticeship contracts in the Dutch Republic. This suggests that most agreements were made either privately or orally. ${ }^{20}$ Those that were put in writing may have contained uncommon elements that motivated the production of legal documentation. In short, notarised apprenticeships cannot be taken as typical. Indeed, eighteenth-century Amsterdam cooper apprentices paid a significantly higher premium (about 10 guilders) whenever an additional contract was mentioned in the guild record, suggesting that written contracts were associated with riskier agreements. ${ }^{21}$

We are therefore reliant on guild records for much of our evidence on early modern Dutch apprenticeship. Arguably, these should still be regarded as primarily being records of private agreements between a master and an apprentice or his guardians. ${ }^{22}$ While contracts had to meet applicable guild regulations, the precise content of the agreement was neither uniform nor prescribed by law. Many aspects were open and could vary significantly, including premiums (fees), terms, board and lodging, details of training, and penalties for early departure. Apprenticeship terms set by guilds were minimum durations. Many apprentices stayed for longer and, more importantly, varying terms, as will be demonstrated. Magistrates were not closely involved in overseeing

${ }^{17}$ Davids, 'Apprenticeship and guild control', 69-70.

${ }^{18}$ On the organisation of Dutch textile manufacturing see H. Soly, 'The political economy of European craft guilds: Power relations and economic strategies of merchants and master artisans in the medieval and early modern textile industries', International Review of Social History 53 (2008), 64-65.

${ }^{19}$ Lourens and Lucassen, 'Oprichting en ontwikkeling', Appendices ('bijlage') 1.2 and 1.3.

${ }^{20}$ Within the digitised notarial deeds from Utrecht between 1670 and 1774 only a few dozen apprenticeship contracts survive, a tiny number compared to the estimated number of Utrecht apprentices (Table 7.1).

${ }^{21}$ Stadsarchief Amsterdam (SAA), Archief Gilden, inv. 895.

${ }^{22}$ I. H. van Eeghen, De gilden: Theorie en praktijk (Bussum: Van Dishoeck, 1974), 20. 
apprenticeships either, although they were sometimes engaged in apprenticing poor boys. ${ }^{23}$ Even then, direct supervision was generally left to civic orphanages or almshouses, which stood in for the parents. ${ }^{24}$

One other major source exists. Civic orphanage records, while not entirely representative, provide insights into the more common crafts, because they apprenticed male orphans with local masters. These were not pauper children. ${ }^{25}$ Civic orphanages, or burgerweeshuizen, only admitted youths whose parents had been middle-class citizens. ${ }^{26}$ By apprenticing them into a craft, they aimed to ensure a similarly secure and prosperous future for them.

Figures on the age of starting an apprenticeship are scarce. Orphans in eighteenth-century Leiden and Utrecht generally began apprenticeships at around 14 years old. Apprentices with the Leiden surgeons' guild between 1702 and 1729 on average started at 14.5 years (standard deviation 2.26). ${ }^{27}$ The vast majority of apprentices in craft guilds were male. Orphanages generally put girls to work as spinners or housemaids. Some crafts were open to females, however - mostly clothing and textile occupations, such as button-making, sewing and weaving. ${ }^{28}$

The local and private character of apprenticeship means that we lack an overview of the number of adolescents entering training across the Dutch Republic. The best measure is the apprenticeship registers of guilds. A considerable number survive for different cities. Table 7.1 reports the existing evidence on the numbers of apprentices in different crafts for several Dutch cities. These figures are, of course, not representative of all craft apprenticeships, but they are the best available guide to the annual flow of apprentices into these urban, guild-controlled crafts. As one would anticipate, the number of apprentices reflects the size of the local craft. Sizeable crafts such as coopering took on relatively more apprentices. It is not surprising that Amsterdam, the country's largest commercial centre, had a large demand for barrels. Haarlem was renowned for its beer manufacturing, resulting in high demand for coopers as well. ${ }^{29}$

${ }^{23}$ Davids, 'Apprenticeship and guild control', 71-72. ${ }^{24}$ McCants, Civic Charity.

${ }^{25}$ N. Bakker, J. Noordam and M. Rietveld-van Wingerden, Vijf eeurwen opvoeden in Nederland: idee en praktijk: 1500-2000 (Assen: Koninklijke Van Gorcum, 2006), 398-99, 411-13.

${ }^{26}$ McCants, Civic Charity, 22-23.

${ }^{27}$ Regionaal Archief Leiden (RAL), Archief Gilden, inv. 351.

${ }^{28}$ B. Panhuysen, Maatwerk: Kleermakers, naaisters, oudkleerkopers en de gilden (1500-1800) (Amsterdam: IISG, 2000); E. van Nederveen Meerkerk and A. Schmidt, 'Between wage labor and vocation: Child labor in Dutch urban industry, 1600-1800', Fournal of Social History 41 (2008), 717-36.

${ }^{29}$ R. W. Unger, 'Technical change in the brewing industry in Germany, the Low Countries, and England in the late Middle Ages', fournal of European Economic History 21 (1992), 289. 
Table 7.1 Number of apprentices for a selection of Dutch crafts and cities, 1588-1799

\begin{tabular}{llrl}
\hline \hline City and craft & Period & Registered apprentices & Average per decade \\
\hline Amsterdam & & & \\
Coopers & $1722-83$ & 5,000 & 806 \\
Pig butchers & $1787-99$ & 517 & 398 \\
Pastry bakers & $1748-74$ & 643 & 238 \\
Surgeons & $1597-1665$ & 1,456 & 211 \\
Masons & $1610-62$ & 700 & 132 \\
Utrecht & & & \\
Blacksmiths & $1646-1795$ & 4,980 & 332 \\
Coopers & $1588-1662$ & 1,062 & 142 \\
Surgeons & $1740-99$ & 614 & 57 \\
Goldsmiths & $1598-1783$ & 1,068 & 36 \\
Art painters & $1611-39$ & 105 & 12 \\
Linen weavers & $1611-1710$ & 121 & 84 \\
Leiden & $1683-1729$ & 394 & 65 \\
Surgeons & $1740-90$ & 332 & 211 \\
Glassmakers & & & \\
Haarlem & $1650-1720$ & 1,500 & 17 \\
Coopers & & & \\
Bois-le-Duc & $1700-98$ & 170 & \\
Goldsmiths & & & \\
\hline \hline
\end{tabular}

Note: Estimates in italics.

Sources: SAA, Archief Gilden, inv. nos. 254, 591, 895, 1349, 1470; Het Utrechts Archief (HUA), Archieven bewaard bij het stadsbestuur I, inv. nos. 105, 124, 131-1; RAL, Archief Gilden, inv. nos. 351, 524; N. Slokker, Ruggengraat van de stedelijke samenleving: De rol van de gilden in de stad Utrecht, 1528-1818 (Amsterdam: Aksant, 2010), 55, 95, 259; Tump,

'Ambachtelijk geschoold', 86; Gemeentearchief Den Bosch, Archief Gilden, inv. 311.

Except for Bois-le-Duc, the cities listed in Table 7.1 all had populations of over 25,000 in 1670. They allow a rough estimate of total apprentice numbers. The table suggests that on average around 19 apprentices enrolled annually per guild. The nine Dutch cities with a population of 25,000 or over contained 296 guilds in total. ${ }^{30}$ This would imply that around 5,500 adolescents started an apprenticeship every year in the nine largest Dutch cities. Amsterdam and Leiden may be somewhat unrepresentative because the former was the largest commercial city and the latter a large textile manufacturer. If we take just the average number of annual apprentices in Utrecht, Haarlem and Bois-le-Duc, then on average 12 apprentices enrolled annually per guild. Multiplying this by the number

${ }^{30}$ Lourens and Lucassen, 'Oprichting en ontwikkeling', Appendix 1.3. 
of Dutch guilds - 1,153 around 1670 - suggests tentatively that approximately 13,800 youths began apprenticeships in the craft guilds of the Dutch Republic each year. ${ }^{31}$

Assuming that apprentices stayed for four years, and that about $60 \%$ fulfilled their contract, ${ }^{32}$ the stock of apprentices in urban crafts would have been about 33,120. The total urban population in the Dutch Republic was 837,000 in $1795 .{ }^{33}$ Apprentices thus made up about $4 \%$ of the urban population. If we repeat the estimate for Utrecht alone, it suggests apprentices formed $4 \%$ of the city's population around 1670 . These estimates are not too far off from the apprentice share of $2 \%-7 \%$ of the urban population calculated for England (see Chapter 9). ${ }^{34}$ The actual number of apprentices surely varied between cities, guilds and periods, but it seems reasonable to imagine that 1 in 12 male inhabitants in Dutch cities was an apprentice. ${ }^{35}$

\section{Enrolling in Apprenticeship}

Apprentices had to pay a small fee when enrolling in an apprenticeship regulated by a guild. At times apprentices from outside the city had to pay more. There was too much local and temporal variation to discern a pattern, although whenever fees did discriminate, they did so against migrants. ${ }^{36}$ For instance, immigrant apprentice surgeons in seventeenthcentury Leiden paid 3 guilders, while locals paid half that. In the Northern Netherlands, the sons of masters (sometimes only the eldest) were often exempt from fees. ${ }^{37}$ The goldsmiths in eighteenth-century Bois-le-Duc charged masters' eldest sons nothing, while other apprentices paid 612 guilders. Sons of Leiden's master surgeons were exempt from fees. More prestigious guilds do not appear to have charged more. ${ }^{38}$ Haarlem silversmiths' apprentices paid about 6 guilders in the eighteenth century,

${ }^{31}$ The number of craft guilds correlates with urban population estimates: ibid., 57.

${ }^{32}$ R. Schalk, P. Wallis, C. Crowston and C. Lemercier, 'Failure or flexibility? Apprenticeship training in premodern Europe', fournal of Interdisciplinary History 48 (2017), 140.

${ }^{33}$ De Vries and van der Woude, First Modern Economy, 857-58.

${ }^{34} \mathrm{~J}$. Humphries, 'English apprenticeship: A neglected factor in the first Industrial Revolution', in: P. A. David and M. Thomas (eds.), The Economic Future in Historical Perspective (Oxford: Oxford University Press, 2003), 79-81.

${ }^{35}$ Figures on urban occupational distributions are not detailed enough to improve this estimate.

${ }^{36}$ Lourens and Lucassen, 'Oprichting en ontwikkeling', 54; J. Tump, 'The coopers' guilds in Holland, c. 1650-1720: A market logic?', in: Davids and De Munck, Innovation and Creativity, 230. There is an overview of apprenticeship fees in the Northern Netherlands in De Munck and Davids, 'Beyond exclusivism', table 9.2.

${ }^{37}$ De Munck and Davids, 'Beyond exclusivism', 201.

38 Tump, 'Ambachtelijk geschoold', 81; De Munck and Davids, 'Beyond exclusivism', 199. 
but Amsterdam surgeons' apprentices only paid 1 guilder at most. ${ }^{39}$ In early modern Utrecht, the fees for all guilds ranged from 1 to 2 guilders; only the goldsmiths' charged outsiders more. ${ }^{40}$

Guild fees for apprentices were not usually used to bar outsiders in the Netherlands, as has been suggested for other parts of Europe. ${ }^{41}$ In late seventeenth-century Zierikzee, in Zeeland, the bakers' guild did raise apprenticeship fees to discourage adolescents, yet most other Zeeland guilds never used fees to limit the number of apprentices. ${ }^{42}$ Apprentices from municipal orphanages or institutions for poor relief were often exempt from fees. In general, the relatively low level of fees that most guilds charged, even for outsiders, meant that they were a limited discouragement to entry. ${ }^{43} \mathrm{~A}$ fee of 6 guilders equated to six skilled daily wages, which seems surmountable. For that reason, Tump argues that the falling number of apprentices in early modern Haarlem reflected adverse economic conditions and war, not high fees. ${ }^{44}$ In other cases, fees were raised not to deter apprentices but to alleviate a guild's financial problems. ${ }^{45}$ Entrance fees for masters, the mastership test and the cost of setting up a shop provided a more challenging hurdle. Mastership fees were much higher than apprenticeship fees. ${ }^{46}$

Another possible barrier to entry were limits on the number of apprentices a master could take. Apprenticeships outside guilds rarely had limitations on apprentices, as Leiden's textile manufacturing demonstrates. ${ }^{47}$ Some guilds did limit the number of apprentices a master could have at any one time, but other guilds had no rule. Surgeons in Amsterdam limited the number of apprentices per master, while the silversmiths and painters in Haarlem and Rotterdam did not. ${ }^{48}$ Whenever these rules were present, as in Utrecht's

${ }^{39}$ Tump, 'Ambachtelijk geschoold', 81; SAA, Archief Gilden, inv. 232, 19.

${ }^{40}$ Slokker, Ruggengraat, 76.

${ }^{41}$ S. Ogilvie, 'Guilds, efficiency, and social capital: Evidence from German proto-industry', Economic History Review 57 (2004), 308.

${ }^{42}$ L. H. Remmerswaal, Een duurzame alliantie: Gilden en regenten in Zeeland, 1600-1800 (Middelburg: Koninklijk Zeeuwsch Genootschap der Wetenschappen, 2009), 96-97.

${ }^{43}$ De Munck and Davids, 'Beyond exclusivism', 203. Although there were certainly exceptions to this rule: Panhuysen, Maatwerk, Bijlage IX.

${ }^{44}$ Tump, 'Ambachtelijk geschoold', 85-86. ${ }^{45}$ Tump, 'The coopers' guilds'.

${ }^{46}$ De Munck and Davids, 'Beyond exclusivism', table 9.2; Panhuysen, Maatwerk, Bijlage IX.

47 Posthumus, Geschiedenis, vol. 3, 355, 613, 701. Only one of six neringen set a (relatively high) maximum of four apprentices: N. W. Posthumus, Bronnen tot de geschiedenis van de Leidsche textielnijverheid 1333-1795, 6 vols. (The Hague: Nijhoff, 1910-22), vol. 5, 301-02. Neringen were corporatist organisations that regulated and oversaw certain branches in the textile industry, usually with the involvement of urban authorities (my interpretation); E. van Nederveen Meerkerk, De draad in eigen handen: vrouwen en loonarbeid in de Nederlandse textielnijverheid, 1581-1810 (Amsterdam: Aksant, 2007), $160-62$.

48 SAA, Archief Gilden, inv. 232, p. 13. Tump, 'Ambachtelijk geschoold', 82-83. 
carpenters' guild, they usually set a limit of one or two apprentices simultaneously. There is no systematic overview of these by-laws. In Utrecht, about half of guilds set limits on apprentice numbers. ${ }^{49}$ In Leiden, too, most surviving by-laws also restricted the number of apprentices.

Masters with fewer apprentices could theoretically devote more time to training each individual. However, high levels of attrition together with apprentices' wages suggest that Dutch apprentices mostly learned by doing, with masters investing little time in direct training. ${ }^{50}$ In that case, limiting numbers would probably not have increased training quality much. ${ }^{51}$ This would imply that these rules may primarily have served to control the size of the craft. Indeed, in 1766 the cloth shearers complained to the Leiden regents that this kind of regulation prevented their trade from expanding. ${ }^{52}$ Data on Leiden orphans shows that the number of starting apprenticeships increased after guilds were abolished around 1820 , even though the orphanage population was stable, suggesting that guilds had been restricting access. ${ }^{53}$ In late eighteenth-century Amsterdam the tailors' guild pursued an active policy of barring outsiders. ${ }^{54}$ Guilds appear to have become more restrictive after the period of economic progress; it is likely they had been less concerned with limiting apprenticeship during the seventeenth-century boom. ${ }^{55}$

Apprentices sometimes paid premiums to their masters as well. Guilds never required premiums. Instead, they were the result of negotiations between master and apprentice. Both premiums and apprentice wages were arguably central to the functioning of the agreement as they (partly) mitigated the risks both parties faced. Recent findings suggest that masters were in practice unable to reclaim their training investments ex post from the cheap labour of the apprentice, because attrition rates were so high. ${ }^{56}$ Under these conditions, it is likely that masters demanded that

${ }^{49}$ Slokker, Ruggengraat, $76 . \quad{ }^{50}$ Schalk, 'From orphan to artisan'.

${ }^{51}$ Further supporting this argument is the observation that many Dutch art painters trained some apprentices simultaneously without this having noticeably affected training quality: M. J. Bok, "Nulla dies sine linie": De opleiding van schilders in Utrecht in de eerste helft van de zeventiende eeuw', De Zeventiende Eeuw 6 (1990), 58-68.

52 Posthumus, Bronnen, vol. 6, 528.

${ }^{53}$ R. Schalk, Splitting the Bill: Matching Schooling to Dutch Labour Markets, 1750-1920 (Amsterdam: Boom, 2015), 71-74.

${ }^{54}$ B. Panhuysen, 'De Amsterdamse en Haarlemse kleermakersgilden en hun concurrenten: De in- en uitsluiting van mededingers op de lokale afzetmarkt in de 17de en 18de eeuw', in: Lis and Soly (eds.), Werelden van verschil, 135.

${ }^{55}$ J. M. Montias, Artists and Artisans in Delft: A Socio-Economic Study of the Seventeenth Century (Princeton: Princeton University Press, 1982), 74 argues that the Delft painters' guild instead tried to protect local painters against the influx of immigrants from the Southern Netherlands.

${ }^{56}$ P. Wallis, 'Apprenticeship and training in premodern England', foumal of Economic History 68 (2008), 832-61; C. Minns and P. Wallis, 'Rules and reality: Quantifying the 
apprentices paid up front for any training not directly covered by the value of their work. Although there are few studies on Dutch premiums, de Jager's work suggests that these extra costs were covered by premiums, while, vice versa, other apprentices paid premiums to speed up training. Premiums for artists' and gold and silversmiths' apprentices in the seventeenth century reflected the duration of the contract (longer apprenticeships were cheaper), board and lodging, the quality of instruction and materials, and the master's reputation. ${ }^{57}$

The use of premiums to speed up skill formation can be seen elsewhere too. For example, in 1696 Willem van der Kloest paid a premium of 6 guilders to Leiden surgeon Johannes Lasar explicitly to 'reduce the term'. ${ }^{58}$ Willem did indeed manage to complete his apprenticeship more quickly than usual. Cooper apprentices from Haarlem also shortened their terms by paying higher premiums. ${ }^{59}$ This tendency to pay for additional instruction up front can also explain why premiums were more common in prestigious crafts, such as those examined by de Jager. As masters in these trades could not depend on learning-bydoing to transfer skills, they had to invest more time in actual training time which was paid for by premiums. Conversely, apprentices who already possessed skills paid lower premiums because of their value in the workshop. ${ }^{60}$

The same logic explains why boarding apprentices paid extra: because they had to cover their food and lodging, especially when the value of their labour was not yet sufficient to meet these expenses. A notarial apprenticeship contract made by an Utrecht goldsmith in 1714 specified that the premium funded board and keep only. ${ }^{61}$ Non-boarding apprentices thus paid less. Orphanages, for example, only rarely paid a premium to the masters who took their boys, and the youths even received wages from the start of their contract. Why? Because apprenticed orphans returned to the orphanage every evening. And as they became more skilled, their wages increased annually. ${ }^{62}$ Similarly, many regular apprentices in cooping and glassmaking received wages from the

practice of apprenticeship in early modern England', Economic History Review 65 (2012), 556-79; Schalk, 'From orphan to artisan'.

${ }^{57}$ R. de Jager, 'Meester, leerjongen, leertijd: Een analyse van zeventiende-eeuwse NoordNederlandse leerlingcontracten van kunstschilders, goud- en zilversmeden', OudHolland 104 (1990), 69-110.

${ }^{58}$ RAL, Archief Gilden, inv. 351, fol. 32. ${ }^{59}$ Tump, 'Ambachtelijk geschoold', 89.

${ }^{60}$ Van Eeghen, De gilden, 24, 77. Cf. C. Minns and P. Wallis, 'The price of human capital in a pre-industrial economy: Premiums and apprenticeship contracts in 18th century England', Explorations in Economic History 50 (2013), 335-50.

${ }^{61}$ HUA, Notarieel Archief, inv. U083b034 deed no. 46

${ }^{62}$ Schalk, 'From orphan to artisan', 740-44. 
start, and paid no premium. ${ }^{63}$ The difference with their premiumpaying counterparts, appearing in the same ledger, was presumably that they were not boarding. As apprentices became more valuable, they covered more of their subsistence. This is illustrated in an Utrecht clothworker's apprenticeship contract from 1706. The apprentice paid 200 guilders for board and training the first year, but only 150 the next. ${ }^{64}$

A random sample of 510 Amsterdam coopers' contracts from the eighteenth century (1722-83) sheds further light on the relationship between premiums and apprenticeship terms. ${ }^{65}$ Excluding contracts that give no information about wages or premiums (193), about $37 \%$ of apprentices paid a premium. This group probably boarded with their masters. Another 52 apprentices did not pay a premium, but also did not receive a wage. The remaining 149 apprentices received a wage during their term, and presumably continued to live at home. For six, the wage started in the second year of their contract. The rest were paid a wage from the start, suggesting that they were already valuable to their master.

The duration of these contracts indicates that premiums could accelerate training. Apprenticeships involving a premium were generally shorter than apprenticeships in which the master paid a wage. Among those with a premium, $48 \%$ lasted two years or less. Only $18 \%$ of apprenticeships with wages were that brief. Plausibly, apprentices who paid a premium expected to become skilled relatively quickly. Apprentices who were unable or unwilling to pay a premium may have been less likely to live with their master, and repaid their training by performing more labour over longer terms.

Nevertheless, some premium-paying apprentices served comparable terms to waged apprentices. Moreover, the size of the premium was not inversely proportional to the contract term. As Table 7.2 shows, higher premiums did not significantly shorten apprenticeships. There was no significant difference between premiums for apprenticeships lasting two years and those lasting four years. However, the large variation in premiums paid for contracts lasting the same duration suggests the importance of other factors, such as particularly able masters, or better quality training and board and lodging. Unfortunately, the sample is too small to explore these characteristics in more detail.

${ }^{63}$ See also R. Reith, 'Apprentices in the German and Austrian crafts in early modern times: Apprentices as wage earners?', in: De Munck, Kaplan and Soly (eds.), Learning on the Shop Floor, 179-202.

${ }^{64}$ HUA, Notarieel Archief, U093a050, deed no. 60.

${ }^{65}$ SAA, Archief Gilden, inv. 895. The sample has been constructed by taking every second apprenticeship contract from each page. 
Table 7.2 Premiums (guilders) of a sample of Amsterdam cooper apprentices, 1722-83

\begin{tabular}{lrrrrl}
\hline \hline Term (years) & N & Mean & St. dev. & Min. & Max. \\
\hline 1 & 3 & 36.67 & 20.82 & 20 & 60 \\
2 & 53 & 30.30 & 11.67 & 8 & 60 \\
3 & 17 & 25.00 & 7.52 & 15 & 40 \\
4 & 42 & 30.19 & 12.17 & 8 & 50 \\
Total & 115 & 29.64 & 11.65 & 8 & 60 \\
\hline \hline
\end{tabular}

Source: SAA, Archief Gilden, inv. 895.

\section{Completing an Apprenticeship}

After paying guild fees and any premium the apprenticeship could begin. Unfortunately, what actually happened on the shop floor is difficult to tell. It seems most likely that apprentices carried out relatively simple chores at first and gradually undertook more skilled work. Masters in the crafts probably provided little direct training, perhaps giving somewhat more to apprentices who paid premiums. Apprentices mostly gained skills through imitation and learning-by-doing. As a result, training was prolonged whenever no premium was paid.

The terms set by guilds varied by city and guild, and were at times altered. Guilds rarely demanded terms longer than five years. Usually, their requirements were much shorter. Surgeon's apprentices in Leiden had to serve five years, but the Haarlem coopers' and the Amsterdam pig butchers' only required two years. ${ }^{66}$ In seventeenth-century Utrecht, minimum terms were set by 22 of the 27 guilds. Only three guilds exceeded two years (the glassmakers, goldsmiths, and lace workers). ${ }^{67}$ In Bois-le-Duc, similarly, 14 guilds required terms of two years, 4 expected three years and only 2 demanded four years. ${ }^{68}$ Although some guild rules envisaged a longer term for immigrants, in practice they served the same term as locals. ${ }^{69}$

Most guilds or masters issued a leerbrief, a written proof of completion, once apprentices completed these minimum terms. It is likely that apprentices wishing to enter the craft adhered to this requirement, because they were usually required to show their leerbrief to work as

${ }^{66}$ RAL, Archief Gilden, inv. 311; Tump, 'Ambachtelijk geschoold', 88; SAA, Archief Gilden, inv. 1470.

${ }^{67}$ Slokker, Ruggengraat, 76.

${ }^{68}$ H. B. M. Essink, Inventaris van de archieven van de ambachts-en schuttersgilden 1327-1874

(n.p, n.d.), 6.

69 Tump, 'Ambachtelijk geschoold', 89. 
a journeyman. In practice, many apprentices probably stayed for terms that were longer than the guild required in order to actually master their craft. Moreover, as the premiums imply, apprentices' actual terms were also affected by the distribution of working and training over their contract. Depending on their contract, apprentices with the same master could serve different terms.

Contracts are only an indirect measure for the actual terms that apprentices served. Early exits were common in Dutch apprenticeships (as will be discussed later). Contracts do nevertheless indicate the length of time agreed between masters and apprentices at the outset. When combined with the information contracts include on wages, we can identify the term that inexperienced, non-boarding apprentices anticipated needing to learn the craft. New apprentices at the Amsterdam coopers' guild between 1722 and 1785 agreed to a term of 3.75 years (median 4 ) on average. ${ }^{70}$ Glassmaking apprentices in eighteenth-century Leiden agreed to an almost identical 3.74 years, on average. ${ }^{71}$

Apprenticeships of orphans provide information about terms that were actually served. Orphans entered relatively common crafts, and were by and large comparable to regular apprentices. ${ }^{72}$ They often appeared alongside regular apprentices in guild records, and their terms were not affected by the time they spent at the orphanage. Figure 7.1 gives the distribution of terms served by orphans in eighteenth-century Leiden and Utrecht, grouped by occupation. Note that these are not contracts, but the actual terms they served.

The figure reveals that the terms that apprentices served within a craft could vary substantially. The shorter terms of around one year mostly relate to apprentices who dropped out or changed masters: almost half moved to a different master or craft, and thus did not complete their training with the first master. We do not know if all apprentices were as mobile as these orphans, but other evidence suggests that around $12 \%$ moved masters within the same guild (for orphans we also count moves to different guilds), while a similar share quit. It is therefore possible that all apprentices behaved similarly.

Figure 7.1 also shows that a significant share of apprentices served terms that were substantially longer than the 2-3 years required by most guilds. Many stayed for five or more years past the point they qualified for a leerbrief. Either it took some time to master a craft, or orphans struggled to move on to journeywork. When orphans from Leiden remained in one

\footnotetext{
${ }^{70} \mathrm{~N}=550$. SAA, Archief Gilden, inv. 895. The start of an apprenticeship is identified by a wage of 12 stuivers at most.

${ }^{71} \mathrm{~N}=30$. RAL, Archief Gilden, inv. 524.

${ }^{72}$ Schalk, 'From orphan to artisan', 733-36.
} 


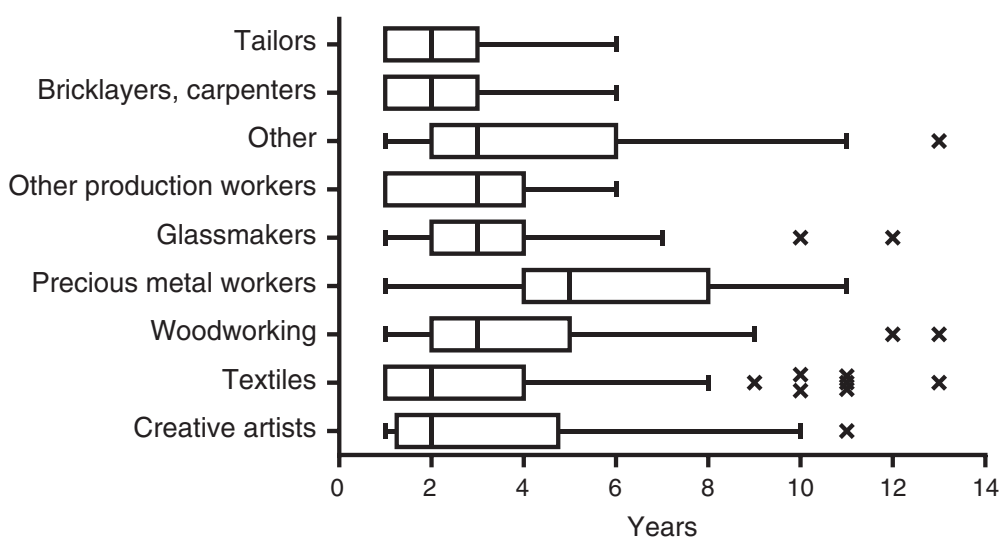

Figure 7.1 Actual terms served by apprenticed orphans from Leiden (1754-82) and Utrecht (1779-93)

Note: $\mathrm{N}=428$. The boxes represent the middle $50 \%$ of individuals, with the vertical line at the median. The whiskers extend for the remaining $25 \%$; where no whisker is included, the distribution is censored or skewed. Xs are outliers.

Sources: RAL, Archief Heilige Geest, inv. 3855, inv. 3390; HUA, Archief Gereformeerd Burgerweeshuis, inv. 769-2, inv. 723-1.

craft throughout their apprenticeship, the average time it took for them to finish was 6.5 years (standard deviation 3.4). In Utrecht, the average time to completion was 4.5 years (standard deviation 2.5 ). It is difficult to explain this variance, but it surely underlines the diverse experiences of apprentices.

We can also reconstruct the time it took for regular apprentices to become masters in a guild. This was fairly similar between guilds, as Table 7.3 shows. Remarkably, masters' sons took longer to become masters. Possibly, they could only open their shop once their father died. The times taken to make this step seem broadly in line with apprenticeship terms, especially since the standard deviations on the time to master status were around 4-5 years. This meant that the journey from apprentice to master could take anything from 5 to over 20 years, with 8-12 years being fairly commonplace. Leiden surgeons' apprentices were 23.4 years old on average when they became a master between 1700 and 1729 (median 23). Since their apprenticeships started at around 14.5 years old, and were contracted for an average of 3.6 years, this implies that they had worked as journeymen for approximately five years before they set up on their own. 
Table 7.3 Years from beginning an apprenticeship to taking a master's test, Dutch Republic 1588-1799

\begin{tabular}{llllll}
\hline \hline City and guild & Period & $\begin{array}{l}\text { Apprentices } \\
\text { (years) }\end{array}$ & $\begin{array}{l}\text { Masters' } \\
\text { sons (years) }\end{array}$ & $\begin{array}{l}\text { Apprentices } \\
(\mathrm{N})\end{array}$ & $\begin{array}{l}\text { Masters' } \\
\text { sons (N) }\end{array}$ \\
\hline $\begin{array}{l}\text { Amsterdam } \\
\text { Pig butchers }\end{array}$ & $1787-99$ & 8.3 & 11.6 & 25 & 30 \\
$\begin{array}{l}\text { Utrecht } \\
\text { Coopers }\end{array}$ & $1588-1662$ & 10.6 & 13.1 & 84 & 20 \\
$\begin{array}{l}\text { Surgeons } \\
\text { Leiden }\end{array}$ & $1740-93$ & 10 & 14.9 & 42 & 7 \\
$\begin{array}{l}\text { Surgeons } \\
\text { Weighted mean }\end{array}$ & $1683-1729$ & 8.2 & 11.4 & 55 & 12 \\
\hline \hline
\end{tabular}

Note: Sons of masters were identified by matching surnames to existing guild masters, except for Leiden where they are identifiable by apprenticeship fees.

Sources: See Table 7.1.

Becoming a master or even a journeyman was, nevertheless, not the fate of all Dutch apprentices. Guild records allow us to infer how many apprentices completed their terms, and how many later became masters. These were two separate events. Apprenticeship completion meant obtaining the leerbrief, certifying that they were qualified to work as a journeyman, which gave access to journeywork in other cities as well. ${ }^{73}$ To become a master, a journeyman had to acquire the capital for a shop, pay the guild's entrance fee and pass the master's test. Each aspect could involve substantial costs.

If we compare the number of registered apprentices to the number of registered master's tests, it demonstrates that many apprentices never became a master. The Utrecht goldsmiths' guild registered 1,068 apprentices, but only 431 master's test between 1598 and 1783, a rate of 2.5 apprentices for every test. ${ }^{74}$ Some of these new masters may have been journeymen who had been apprentices elsewhere before moving to Utrecht. The Utrecht coopers' guild registered 250 master tests against 1,062 apprentices. ${ }^{75}$ Even in prestigious crafts, some apprentices still would not become a master. Of the 29 apprentices taken by the wellknown Dutch painter Abraham Bloemaert, renowned for his teaching skills, only 15 became master painters. Of the other 14 apprentices, 4

${ }^{73}$ C. Plomp, 'Het leerlingwezen in Den Haag van de 15de tot de 18de eeuw', Die Haghe Faarboek (1936), 16.

${ }^{74}$ HUA, Archieven stadsbestuur I, inv. 130, inv. 131-1.

${ }^{75}$ HUA, Archieven stadsbestuur I, inv. 124. 
died, another 4 entered different trades ( 2 goldsmiths, 1 cloth merchant and 1 in the military) and the remaining 6 apprentices could not be traced. ${ }^{76}$ The fates of apprentices who did not take a master's test remain unknown. Perhaps they entered apprenticeships in other crafts or migrated; others surely worked as journeymen and simply never became master.

Lists of leerbrieven that allow us to distinguish those apprentices who qualified as journeymen rarely survive. However, we have identified them for three guilds: the Amsterdam pig butchers' (1787-1811), the Amsterdam pastry bakers' (1748-76) and the Leiden surgeons' guilds (1683-1729).$^{77}$ In every guild, a considerable share of apprentices did not complete their term. Surgeon apprentices had the highest completion rates, but even in this prestigious craft about $40 \%$ of apprentices dropped out. Half of the pastry bakers' apprentices obtained their leerbrief. At $32 \%$, this share was even lower among pig butchers' apprentices. ${ }^{78}$ These findings are supported by apprenticeship lists from other guilds, which show that attrition was high everywhere. The intervals at which Leiden's glassmakers took new apprentices suggest that at least $16 \%$ of regular contracts were terminated early (freeing the master to hire another youth), while at least $22 \%$ of the apprenticeships of Leiden orphans were abandoned.

The youth's aptness for the craft played a role in whether they decided to stay. Among Leiden orphans, talented apprentices sometimes moved to crafts related to their previous apprenticeship. ${ }^{79}$ For instance, Jan van Kampen switched from chair making to cabinetmaking, earning a higher wage during this second apprenticeship (from 26 to 28 stuivers a week). Changing masters within the same craft also helped apprentices to hone their skills, as is evidenced by their pay; orphans who switched master within a craft nearly always received a wage increase.

Conversely, many apprenticed orphans moved to entirely different crafts when they left their first master. This group experienced a cut in wages. In 1770, when Elias Dionet left his candle-making apprenticeship after six years of service to apprentice as a chair maker, his wage dropped from 22 to 10 stuivers. Orphans who shifted sector were more likely to drop out of training altogether: $80 \%$ of apprentices who moved within

${ }^{76}$ M. Prak, 'Paintings, journeymen painters and painters' guilds during the Dutch Golden Age', in: N. Peeters (ed.), Invisible hands? The role and status of the painter's journeyman in the Low Countries c. 1450-c. 1650 (Leuven: Peeters, 2007), 133-49. See also Montias, Artists and Artisans.

${ }^{77}$ Schalk, Wallis, Crowston and Lemercier, 'Failure or flexibility?', 137.

${ }^{78}$ The pig butchers did not consistently record the fate of all apprentices, but it is likely that unknown observations did not receive their leerbrief.

${ }^{79}$ Schalk, 'From orphan to artisan', 741-42. 
a sector completed their apprenticeship, compared to $58 \%$ of those who moved between sectors. They thus probably moved crafts because they were not suited to their apprenticeships or did not like their craft. This suggests that talented apprentices experienced upward career mobility and higher completion rates, while less talented orphans were gradually filtered out.

The orphanage records are a rare window into these movements. It is much harder to observe regular apprentices. However, guild records show they moved between masters within the guild. Guild regulations allowed masters to transfer apprentices, as long as this was registered sometimes with a fee. The share of apprentices who moved masters at least once ranged from $8.6 \%$ at the Amsterdam pastry bakers' guild to $14.1 \%$ at the Amsterdam pig butchers' guild, while the Utrecht coopers and the Leiden surgeons had shares of $11.4 \%$ and $11.7 \%$ respectively. Interestingly, moving masters did not significantly affect the chance of completion. Dutch apprenticeship was not a rigid system that locked apprentices into their indentures. Instead, they could exit from their agreements or switch masters, just as masters could easily get rid of unsuitable apprentices.

\section{Enforcing Apprenticeship Contracts}

Some historians argue that apprenticeship could only operate when guilds, courts or self-enforcing mechanisms (such as a reputational effect) acted as contract enforcers. ${ }^{80}$ If these mechanisms were absent, the argument goes, the risks involved would have been too high and the system would have collapsed. Others have argued that working and training in tandem reduced this risk, allowing costs and benefits to be roughly balanced throughout the term. ${ }^{81}$ Nevertheless, it is likely that a continuous balance of costs and benefits was not always possible. As a result, mechanisms were needed to resolve conflicts between masters and apprentices resulting from contract frictions. In pre-modern London, for example, the Lord Mayor's Court heard disputes over apprentices' premiums after youths had left their masters. By resolving conflicts, the court lowered the risks of long-term contracts. ${ }^{82}$

${ }^{80}$ S. R. Epstein, 'Craft guilds, apprenticeship, and technological change in preindustrial Europe', Fournal of Economic History 58 (1998), 684-713; Humphries, 'English apprenticeship'.

81 Wallis, 'Apprenticeship and training'; Schalk, 'From orphan to artisan'.

${ }^{82}$ P. Wallis, 'Labor, law, and training in early modern London: Apprenticeships and the City's institutions', fournal of British Studies 51 (2012), 791-819. 
Courts of the same scope and magnitude were not present in the Northern Netherlands, possibly because Dutch apprenticeship was more decentralised (London operated as a national training centre). Dutch cities had various institutions for conflict resolution. The most important were the urban civil court, notaries and guilds. ${ }^{83}$ The urban civil court was often divided into several benches, each serving a selection of topics ranging from major cases, involving lawyers, to neighbourly conflicts and minor credit disputes. ${ }^{84}$ The available literature suggests that civil courts rarely intervened in apprenticeship. In a selection of over 3,000 arbitration cases at the Leiden civil court in 1664, only seven related to labour conflicts. ${ }^{85}$ Most of these concerned journeymen, not apprentices.

In pre-modern Utrecht a separate bench of the civil court handled minor cases (kleine zaken), much like the Leiden civil court of Vredemakers (peacemakers). Many lower to medium-skilled workers appeared here, and suits often related to outstanding payments for goods or wages, house rents, or insults. Almost all cases resulted in financial compensation. It is difficult to be sure whether this court handled all potential apprenticeship conflicts, but several do appear in the list of verdicts. The maximum claim in minor civil courts in the Republic was normally around 50 guilders. ${ }^{86}$ In the Leiden peacemaker court - which seems more or less comparable to the Utrecht minor court - the majority of claims were settled for less than 20 guilders. ${ }^{87}$ This court was mostly used by middling to elite groups from Leiden. Other routes of judicial conflict resolution were more expensive and time consuming. ${ }^{88}$ It is therefore unlikely that craftsmen or apprentices appeared in large numbers before aldermanic courts. ${ }^{89}$

In Utrecht, the civil court's minor bench heard around 360 cases annually in the mid-seventeenth century, gradually declining to about 200 by 1758 . A small share related to apprenticeships. In the sample years $(1653,1655,1658,1662,1663,1670,1674,1689$ and 1758), a total of only 32 apprenticeship conflicts could be found. ${ }^{90}$ In short, the

${ }^{83}$ A. van Meeteren, Op hoop van akkoord: instrumenteel forumgebruik bij geschilbeslechting in Leiden in de zeventiende eeuw (Hilversum: Verloren, 2006).

${ }^{84}$ Ibid., ch. 7 and $8 .{ }^{85}$ Ibid., $269-70$.

${ }^{86}$ C. M. G. ten Raa, De oorsprong van de kantonrechter (Deventer: Kluwer, 1970), 158-76.

${ }^{87}$ G. Vermeesch, 'The social composition of plaintiffs and defendants in the Peacemaker court, Leiden, 1750-54, Social History 4 (2015), 217-18, 223-24.

${ }^{88}$ Ibid., 227-28.

89 Two verdict ledgers of the Utrecht major civil court from 1643 to $1664-74$ contained just one apprenticeship dispute. It concerned a merchant apprentice ejected by his master in 1667 because of misbehaviour. He sought to reclaim the 200 guilders premium he had already paid (the total premium was fl. 400 in two parts). The court ordered the master to refund the premium because he could not prove the apprentice's misbehaviour. HUA, Gerechtelijk Archief, inv. 2266-17, inv. 2826-7, inv. 2566.

${ }^{90}$ HUA, Gerechtelijk archief Utrecht, inv. 3141-1, inv. 3141-2, inv. 3141-3, 3141-5. 
court could settle apprenticeship disputes, but it was rarely used for this purpose.

The cases themselves throw some light on the resolution of apprenticeship conflicts. For instance, in 1689 one master demanded that his runaway apprentice should still pay 20 guilders in premiums. The court agreed that compensation was in order, but only required the apprentice to pay 6 guilders and 6 stuivers. ${ }^{91}$ In another case, a mother paid 18 stuivers to a button-maker to cancel her son's apprenticeship. ${ }^{92}$ In 1670 a father demanded outstanding wages for his apprenticed son. The parties agreed that the master would pay, but only when the apprentice promised to serve the remaining two years of his contract. ${ }^{93}$ Several other masters wanted apprentices to return and finish their terms without any wages as leverage. However, these all relate to low-skilled textile occupations, and may suggest that they simply had problems finding workers. Apart from these instances, the court mainly facilitated exits by settling the bill between masters and apprentices. Either masters needed to pay outstanding wages, or guardians coughed up unpaid premiums or settled living costs.

Notarial records suggest that private conflict resolution offered an alternative route. Private settlements were sometimes recorded in notarial deeds, which could then be used in courts if needed; most of the time, this procedure sufficed to settle the issue. ${ }^{94}$ Some apprenticeship contracts at Utrecht notaries, for example, contain a clause in which apprentices pay a fine should they leave their master. ${ }^{95}$ This could work both ways: in 1691 a Utrecht watchmaker promised a reward of 100 guilders if his apprentice served his full term. Should he leave early, however, the apprentice had to pay 100 guilders to the master. ${ }^{96}$ In 1669 , the pharmacist Henricks Junius declared that he was willing to release his apprentice, Petrus Polion, whom he had hired in 1666. In return, Polion's father paid 115 guilders as compensation for board and keep. ${ }^{97}$ Although a more detailed examination of notarial deeds is required to better understand the role of notaries in contract enforcement, these examples demonstrate that parties could settle contracts in private.

There is little evidence that guilds acted as mediators in apprenticeship conflicts. Guilds in the Dutch Republic were preoccupied with trying to

${ }^{91}$ HUA, Gerechtelijk archief Utrecht, inv. 3141-5, 21 January 1689.

${ }^{92}$ HUA, Gerechtelijk archief Utrecht, inv. 3141-1, 24 April 1655.

${ }^{93}$ HUA, Gerechtelijk archief Utrecht, inv. 3141-3, 29 November 1670.

${ }_{94}$ Cf. Van Meeteren, Op hoop van akkoord, 172-74.

${ }^{95}$ HUA, Notarieel archief, inv. U138a007 deed no. 165; inv. U083b034, deed no. 46.

${ }^{96}$ HUA, Notarieel archief, inv. U123a001 deed no. 106.

${ }^{97}$ HUA, Notarieel archief, inv. U048a003, deed no. 573. For a comparable resolution see HUA, Notarieel archief, inv. U075c001 deed no. 180. 
enforce their monopolies and uphold their regulations. Enforcing apprenticeship was not a priority. Guilds only attended to apprenticeship when masters hired more apprentices than they were allowed, or the acceptance or transfer of youths had not been registered. ${ }^{98}$ Although the records of guild meetings have not survived as often as apprenticeship lists, those that do exist are generally silent on contract enforcement. For example, between 1666 and 1782 the Amsterdam blacksmiths' guild dealt with conflicts about payments between guild members and suppliers, and fined members who breached regulations. Yet conflicts about apprentices never appear in the ledger..$^{99}$ Guild officials appeared before the Utrecht minor court demanding fines from guild members who had hired too many apprentices or failed to pay their membership dues. ${ }^{100}$ That Dutch guilds themselves resorted to external judicial forums further argues against them having a role as contract enforcer.

Take Utrecht: the city contained around 39 guilds around 1670, suggesting that around 468 youths began apprenticeships each year. Around 187 of these apprentices would later drop out. ${ }^{101}$ Yet in the three years 1653,1655 and 1658 only a total of 11 apprenticeship conflicts were heard by the court's minor bench, just a couple of apprentice agreements were notarised, and there is no evidence in the surviving guild records that they enforced contracts. Apparently, only a tiny minority of masters and apprentices resorted to formal conflict resolution. Perhaps they could reach a private understanding. The evidence of the Leiden orphans suggest that many apprenticeships ended without much conflict. Orphans were apprenticed to almost one hundred different masters between 1754 and 1782. Many moved masters or abandoned their contracts. Yet only two masters complained to the orphanage's regents over breach of contract. ${ }^{102}$

\section{Apprentices versus Masters}

Since many apprentices dropped out during their apprenticeship, it is not surprising that the share of apprentices becoming masters was low. Ten per cent of apprentices in the Utrecht coopers' guild between 1588 and 1662 took the master's test (see Table 7.4). For the Leiden (1683-1729) and Utrecht (1740-99) surgeons' guilds the shares were 14.4 and $8.7 \%$ of

\footnotetext{
${ }^{98}$ Davids, 'Apprenticeship and guild control', 67-70.

${ }^{99}$ SAA, Archief Gilden, inv. 1435.

100 HUA, Gerechtelijk archief Utrecht, inv. 3141-3, dated 12 September 1670 and dated 26 September 1670.

${ }^{101}$ Utrecht guild population from Lourens and Lucassen, 'Oprichting en ontwikkeling', 69.

102 Schalk, 'From orphan to artisan', 746.
} 
Table 7.4 Number of apprentices taking their master's test with the Utrecht coopers' guild, 1588-1662

\begin{tabular}{lccc}
\hline \hline Period & Apprentices & Became master & $\%$ \\
\hline $1588-99$ & 111 & 14 & 13 \\
$1600-09$ & 99 & 15 & 15 \\
$1610-19$ & 149 & 21 & 14 \\
$1620-29$ & 134 & 14 & 10 \\
$1630-39$ & 171 & 17 & 10 \\
$1640-49$ & 168 & 12 & 7 \\
$1650-62$ & 230 & 11 & 5 \\
$1588-1662$ & 1,062 & 104 & 10 \\
\hline \hline
\end{tabular}

Source: HUA, Archieven stadsbestuur I, inv. 124.

apprentices, respectively. Among the Amsterdam pig butchers' apprentices, $10.6 \%$ took the master's test. These are lower bound estimates: some individual links will have been missed, and some apprentices became masters in another city. ${ }^{103}$ In turn, the Utrecht coopers' guild accepted several masters who had joined as immigrant journeymen.

Becoming a master was easier for apprentices who were related to a master in the guild. Although masters' sons took somewhat longer to become a master (Table 7.3), more of them did so than we see among other apprentices. In the Leiden surgeons' guild about $22 \%$ of apprentices who were masters' son took the master's test, compared to $16 \%$ of local apprentices. Only $4 \%$ of apprentices from outside Leiden became masters. Sons of Utrecht master coopers were almost five times more likely to become a master than other apprentices.

Although the share of apprentices who became a master varied by guild, in general the great majority of apprentices would not become a master in the same city, even if they completed their apprenticeship. In the Leiden surgeons' guild, of the 394 boys who started apprenticeships between 1683 and 1729, 237 completed their term; yet only 57 became masters in Leiden. Just one in four locally qualified journeymen took their master's test. Similarly, approximately one in three journeymen in the Amsterdam pig butchers' guild became masters.

If these guilds were typical, they imply that crafts displayed a pyramidshaped hierarchical distribution, with a broad base of apprentices and a relatively small number of masters. That the number of masters was

${ }^{103}$ At both surgeons' guilds full names are spelled in such a standardised manner that mismatching is unlikely. 
smaller than the number of journeymen and apprentices seems reasonable. However, it is unlikely that every master employed two to three journeymen, as these estimates could imply. In the Amsterdam blacksmiths' guild only one-quarter of masters had more than one journeyman in $1794 .^{104}$ The guild numbered 101 masters and 142 journeymen in that year. These figures indicate that a substantial share of the apprentices who qualified as journeymen but never became masters must have left the trade altogether, or migrated to another city. Unfortunately very little is known about these people. ${ }^{105}$

Many masters did not take on apprentices. Even in guilds that limited the number of apprentices, a large share of masters never provided training. ${ }^{106}$ It is difficult to judge whether non-training masters simply did not want apprentices, or whether the supply of training exceeded demand. Masters who provided training nevertheless appear to have done so almost without interruption, taking a new apprentice as soon as one left. This could be interpreted as a market where demand exceeded supply, because training masters could always find new apprentices.

The distribution of apprentices among different masters was skewed in all observed guilds. Although for most guilds we only observe masters who did provide training, Figure 7.2 clearly shows that a small share of masters took most apprentices. When all masters are included, as for the Amsterdam pastry bakers, the distribution becomes even more skewed. In this guild, $30 \%$ of masters took no apprentices between 1750 and 1775 . In all these guilds, $20 \%$ of (training) masters took approximately $50 \%$ of apprentices.

\section{Dutch Apprenticeship after the Guilds ${ }^{107}$}

After a long political struggle, Dutch guilds were abolished around $1820 .{ }^{108}$ How did this affect apprenticeship training? Evidence on orphan apprenticeships indicates that some features remained as before. ${ }^{109}$ Apprenticed orphans in Leiden around 1850 and Utrecht around 1860 served similar apprenticeships to orphans who had trained a century earlier when apprenticeships were monitored by guilds. Completion rates in Leiden and Utrecht were much the same in the eighteenth century and

${ }^{104}$ SAA, Archief Gilden, inv. 1494.

105 J. Lucassen and L. Lucassen, 'The mobility transition revisited, 1500-1900: What the case of Europe can offer to global history', Fournal of Global History 4 (2009), 363-64.

${ }^{106}$ Bok, 'Nulla dies sine linie'.

107 This paragraph summarises the results of Schalk, Splitting the Bill, chapter 3.

${ }^{108}$ De Munck, Lourens and Lucassen, 'Establishment and distribution of craft guilds', 65-66.

109 Schalk, 'From orphan to artisan', 748-53. 


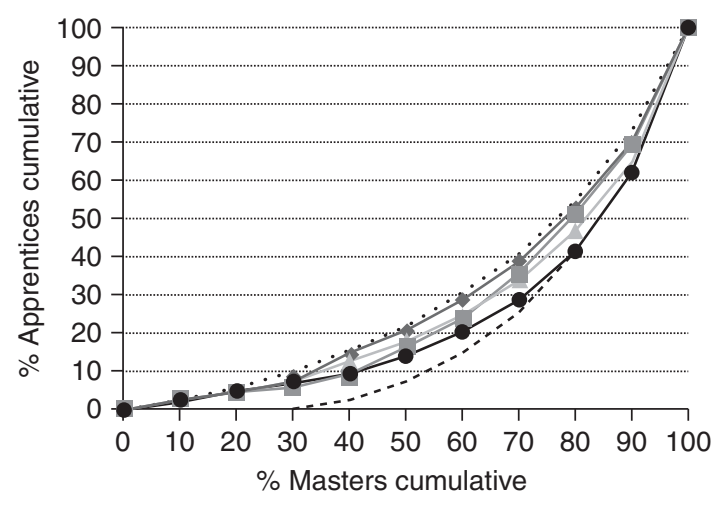

$\rightarrow$ Utrecht coopers 1588-1662, only training masters $(n=1,207)$

-- Utrecht surgeons 1740-99, only training masters $(n=614)$

- Amsterdam butchers 1787-1811, only training masters $(n=607)$

$\neg \quad$ Leiden surgeons 1683-1729, only training masters $(n=623)$

... Amsterdam pastry bakers $1750-75$, only training masters $(n=784)$

... Amsterdam pastry bakers $1750-75$, all masters $(n=784)$

Figure 7.2 Distribution of apprentices among masters for various Dutch guilds, 1588-1811

Notes: The number of observations is in some cases different from Table 7.1 because some apprentices may have had multiple masters.

Sources: See Table 7.1.

the first half of the nineteenth century. Apprenticeship did not become more uncertain after the guilds.

However, nineteenth-century adolescents did have many more craft apprenticeships to choose from. Especially in Leiden, orphans were apprenticed to a broader range of crafts than they had been under the guilds. The number of apprentices per master also changed. Several masters in Leiden and Utrecht now took on more apprentices than had been permitted by guild regulations. Both developments suggest that guilds had in fact limited access to training.

Other than increased access, Dutch masters and apprentices before industrialisation operated in a training market that functioned very much as it had a century before. Both parties had sufficient reasons to partake in training, and as a result enforcement was not a problem. Orphanage records do not show an increase in disputes after the guilds disappeared, and the literature on the abolition of Dutch guilds makes little mention of 
any effects on apprenticeship. ${ }^{110}$ Proponents of the re-establishment of guilds mostly complained about the loss of ways to evaluate product quality. ${ }^{111}$ They were also mostly concerned about losing their monopolies. Nor were politicians worried about a decline of apprenticeship without the guilds. ${ }^{112}$

At the dawn of Dutch industrialisation this relatively unregulated and unmonitored vocational training market nevertheless displayed some problems. The incentive structure for both masters and apprentices was altered by, first, the growing demand for unskilled labour and, second, increasing division of labour. The first cut demand for apprentices, while the second reduced masters' interest in providing training. Under the guilds, apprentices perhaps accepted their position in the expectation that it won them access to a privileged labour market with higher wages. With skill certification essentially absent after the guilds' abolition, apprenticeship was no longer the only route to skilled work. The increasing division of labour and associated deskilling in turn would have caused masters to avoid training, using apprentices as cheap labourers instead - further lowering the appeal of apprenticeship. ${ }^{113}$ As a result, apprenticeship probably declined when the Dutch economy industrialised around the 1870s.

There is, however, little firm data on apprenticeship during industrialisation. Formal, firm-level apprenticeships seem to have been rare. ${ }^{114}$ Only a handful of larger firms, such as the electrical company Philips, the machine factory Stork and some railway companies, offered formal apprenticeships around $1900 .{ }^{115}$ Since few third parties monitored or regulated them, these apprenticeships may have been relatively informal

110 C. Wiskerke, De afschaffing der gilden in Nederland (Amsterdam: Paris, 1938); Davids, 'Apprenticeship and guild control', 78.

111 M. Prak, Republikeinse veelheid, democratisch enkelvoud: sociale verandering in het Revolutietijdvak, 's-Hertogenbosch 1770-1820 (Nijmegen: SUN, 1999), 98-100, 279-84.

112 A search of digitised Dutch parliamentary debates between 1810 and 1850 using different key words relating to guilds and apprenticeship shows that neither guilds, their proponents nor politicians perceived of a link between the abolition of the guilds and a possible decline of apprenticeship: www.statengeneraaldigitaal.nl.

113 The relatively open labour market may have caused masters or journeymen to refrain from training because they feared they would 'glut their trade'; K. D. M. Snell, 'The apprenticeship system in British history: The fragmentation of a cultural institution', History of Education 25 (1996), 317.

${ }^{114}$ H. P. Meppelink, Technisch vakonderwijs voor jongens in Nederland in de 19 e eeuw (n.p, 1961), 86-91.

115 G. J. de Groot, Fabricage van verschillen: mannenwerk, vrouwenwerk in de Nederlandse industrie (1850-1940) (Amsterdam: Aksant, 2001); C. Beets, Tachtig jaar Stork (n.p, 1948); P. W. N. M. Dehing, Eene soort van dynastie van spoorwegbeambten: Arbeidsmarkt en spoorwegen in Nederland, 1875-1914 (Hilversum: Verloren, 1989), 49-52. 
on-the-job training. ${ }^{116}$ The Vocational Training Act regulating apprenticeships was introduced in $1919 .{ }^{117}$ However, as late as 1928 only the metal industry had an industry-wide apprenticeship system, with about 2,000 participants. ${ }^{118}$

One party that monitored apprenticeships and on-the-job training before 1919 was, once again, municipal orphanages. As before, orphanages continued to record orphans' training and wages as they sought to ensure that youths learned a trade - and were able to leave the orphanage once grown. The Amsterdam Diaconieweeshuis der Hervormde Gemeente (the Reformed Orphanage) kept a register listing the on-the-job training of all male orphans from 1887 to $1902 .{ }^{119}$ It includes the employer's name and occupation, the orphans employed, the period of employment and the reason employment ended. The register covers the training of 327 Amsterdam orphans who undertook over 1,400 placements with local employers.

Relations between orphans and their bosses had become more insecure, at least in Amsterdam. Figure 7.3 gives the distribution of the periods that orphans spent with each employer by craft. It captures about $70 \%$ of all placements. The majority of all placements were very short. More often than not, the median term was a mere 4-7 months. Only around $20 \%$ of placements lasted for longer than one year. Tellingly, $62 \%$ lasted between a couple of days and six months. With an overall median duration of five months (and a mode of three months), the periods that Amsterdam orphans spent with employers were now much shorter than those experienced by Leiden and Utrecht orphans in the early nineteenth century.

Figure 7.4 examines the reasons recorded by the orphanage for agreements ending. These short terms were caused by insecurity on both sides: adolescents could lose their job at any moment and bosses were never sure that adolescent workers would return the next day. In $61 \%$ of cases, the employer ended the agreement, while orphans initiated the termination of $30 \%$. In the remaining $9 \%$, the regents removed the orphan. ${ }^{120}$

${ }^{116}$ K. M. Anderson, 'The long road to collective skill formation in the Netherlands', in: M. R. Busemeyer and C. Trampusch (eds.), The Political Economy of Collective Skill Formation (Oxford: Oxford University Press, 2012), 112.

${ }^{117} \mathrm{C}$. Trampusch, 'Co-evolution of skills and welfare in coordinated market economies? A comparative historical analysis of Denmark, the Netherlands and Switzerland', European Fournal of Industrial Relations 16 (2010), 202.

${ }^{118}$ De Ingenieur; T. Technische Economie, Nr. 49 (1928) [Bijlage], 66-69.

119 SAA, Diaconieweeshuis der Hervormde Gemeente, inv. 1006.

120 Cf. J. Giele (ed.),De arbeidsenquête van 1887: Een kwaad leven: heruitgave van de 'Enquête betreffende werking en uitbreiding der wet van 19 September 1874 (Staatsblad $n^{\circ} 130$ ) en naar den toestand van fabrieken en werkplaatsen' (Nijmegen: Link, 1981), vol. 1, response no. 1334. 


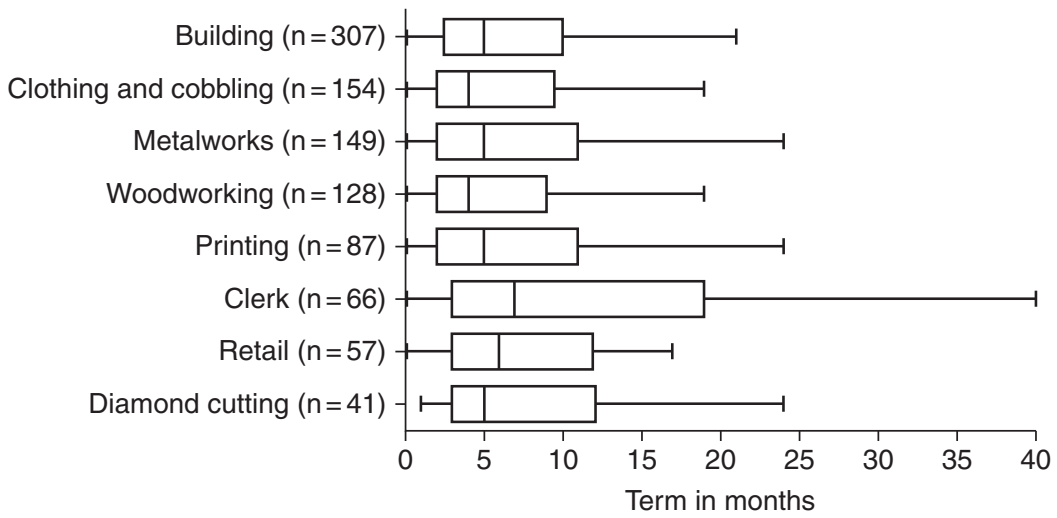

Figure 7.3 Distribution of placements of Amsterdam orphans, 1887-1902

Note: The boxes represent the middle $50 \%$ of individuals, with the vertical line at the median. The whiskers extend for the remaining $25 \%$. Source: Schalk, Splitting the Bill, 91.
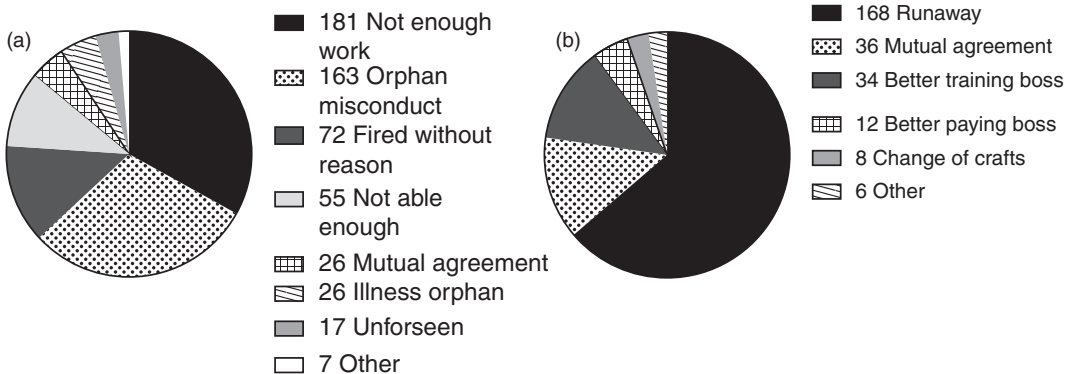

$\square$ Other

Figure 7.4 Reasons for terminating on-the-job training of Amsterdam orphans, 1887-1902

Note: $\mathrm{n}=886$; (a) by employers (b) by orphans.

Source: Schalk, Splitting the Bill, 92.

Training ended by mutual agreement in only $8 \%$ of cases. One orphan, Buckert, for instance, began training with a carpenter in 1890. By the time he left the orphanage in 1895 , he had worked for no less than 16 employers. Buckert was never fired because he was unwilling or misbehaving, but simply because the carpenter temporarily had insufficient work. Although he eventually managed to become a carpenter, this was despite and not because of this large number of employers. Employers did also object to the conduct of many orphans, 


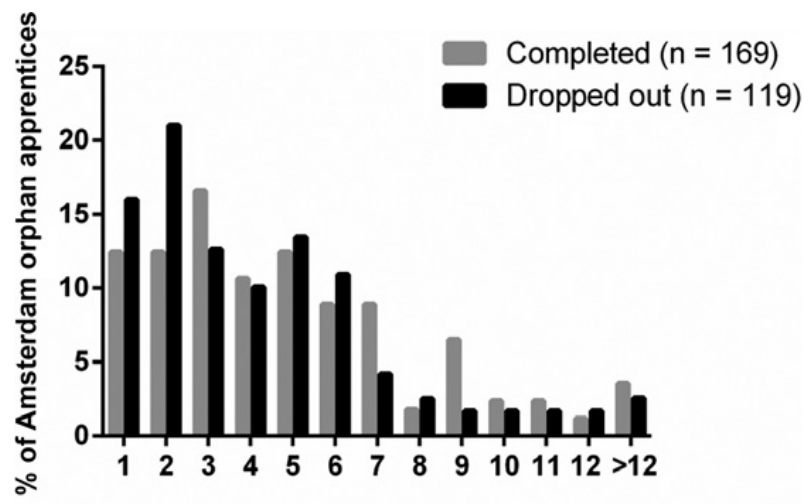

Employers

Figure 7.5 Number of employers during on-the-job training of Amsterdam orphans, 1887-1902

Source: Schalk, Splitting the Bill, 93.

though we cannot tell if these orphans were troublemakers or if their employers were just finding a reason to fire them. Missing one day's work because of illness was reason enough for some bosses to end a placement. On the other hand, many orphans simply did not turn up for work. Orphans could, and did, leave at any moment. An offer of better training or pay was enough for orphans to quit, but most gave no reason. Generally, these orphans remained at the orphanage, so the regents had to find yet another employer.

Faced with brief and insecure jobs, orphans had to work for multiple firms to become skilled. Orphan Weggelaar was fired by no less than four cabinetmakers because there was too little work. ${ }^{121}$ Although in total he spent more than three years as a cabinetmaker's apprentice, because work was slow he had probably learned little. When apprenticed at yet another cabinetmaker in 1892 he was, ironically, fired because of insufficient skills. As Figure 7.5 shows, it was common for orphans to have several employers while living at the orphanage. The number of placements had increased dramatically compared to that experienced by Leiden and Utrecht orphans apprenticed before industrialisation. Because the process of skill formation was erratic, orphans found it harder to leave the orphanage. In December 1897, some complained to the regents that their earnings were too low to support themselves. The regents decided that in future not only age but also weekly earnings should be

121 SAA, Diaconieweeshuis der Hervormde Gemeente, inv. 1006, fol. 30. 
considered when deciding to discharge orphans. ${ }^{122}$ Apparently, industrial on-the-job training resulted in too little skill formation, and hence in low wages.

Whether the instability of on-the-job training was caused by weaker enforcement remains an open question. As we saw, formal enforcement mechanisms were rarely used in the pre-modern period, making it unlikely that their withdrawal lay behind this. Moreover, courts could still enforce contracts. In 1907, when a father wanted to cancel the diamond-cutting apprenticeship of his daughter due to the master's absence, he took the case to court - which ruled against him, concluding that the master did not have to be present all the time. ${ }^{123}$ Whether such cases became more common during industrialisation is unclear, but the legal journal that included this case does not appear to have covered other apprenticeship conflicts in this period. Perhaps apprenticeship had become so informal that few contracts were conducted, rendering them unenforceable in the courts. Apparently, most accepted the increased uncertainty prevalent in on-the-job training.

Thus, by the end of the nineteenth century skill formation in the Dutch craft sector was mostly left to chance and perseverance, even when orphanage regents could have tried to enforce agreements. Only the most adamant and motivated adolescents would become skilled workers. Even after training they had limited ways to signal their skills to other employers. 'These days, boys can no longer learn their craft from bosses', an inspector of secondary education lamented in $1890 .^{124}$ A lengthy contribution in the journal of the Dutch Society to Advance Industry in 1891 criticised the condition of Dutch training in detail: 'Nowadays boys leave one boss after the other for the greatest triviality .... The boss continuously fears that the boy will leave him to use his acquired skills with another boss. Bosses therefore slow down training by putting boys to work at specialised repetitive tasks, so that they bring in the highest profits.' ${ }^{125}$ This caused an abundant supply of mediocre workers to the detriment of skilled workers. ${ }^{126}$ Incidental remarks from labour reports underline that these conditions applied more generally.

The decline of apprenticeship was possibly countered by the establishment of vocational evening and daytime schools, which were founded in

\footnotetext{
122 SAA, Diaconieweeshuis der Hervormde Gemeente, inv. 1006, minutes of 16 December 1897.

123 Weekblad van het Recht, No. 8985 (29-10-1910), 4-5.

124 Arbeidsenquete 1890: Tweede afdeeling: Zwolle, Deventer, Kampen, response no. 1607.

125 Orgaan der Nederlandsche Maatschappij ter bevordering van Nijverheid, vol. 2 (1891), 97.

126 Ibid., 96.
} 
increasing numbers from the late nineteenth century. Educational and occupational data from Dutch conscripts suggests that these schools did not directly result in higher wages compared to workers trained on-thejob. Nevertheless, vocational degrees did significantly increase the probability of landing a job as a skilled worker, while lowering the chance of becoming an unskilled worker. ${ }^{127}$ The absence of skill certification, then, may have been one reason behind the decline in apprenticeship in the later nineteenth century.

\section{Conclusion}

During the pre-industrial period, apprenticeships in the crafts looked similar throughout the cities of the Northern Netherlands. Everywhere, contracts settled individual agreements between masters and adolescents. Guild by-laws concerning apprenticeship did vary, but Dutch guilds generally regulated only a few elements: guild fees, (minimum) terms and sometimes the number of apprentices per master. Most other aspects of an apprenticeship were open to negotiation between masters and apprentices. Apprenticeships could be heterogeneous as a result, even within the same craft, or within one master's workshop. Terms, for instance, varied according to the apprentice's skills, his contribution to the workshop and his premium. Nevertheless, in all crafts apprenticeship functioned similarly, with relatively flexible agreements between masters and apprentices.

Apprenticeship contracts were also quite uncertain. In many guilds, a large share of apprentices dropped out during their training; even those who qualified as journeymen often did not become a master. Sons of masters were most likely to complete apprenticeships and to become masters. Sons of masters were also often exempt from guild regulations on apprenticeships. Guilds may sometimes have reduced access to training for youths who were not masters' sons, although this effect varied across guilds. The distribution of apprentices demonstrates that most craft training was supplied by a small number of masters, and this possibly affected access as well.

Apprenticeship survived the abolition of the guilds in the Netherlands, yet it came under pressure during industrialisation in the later nineteenth century. The increasing division of labour coupled with deskilling put further strain on the mix of incentives that had allowed apprenticeship training to work well previously. Together with the loss of skill certification and relatively open labour markets, both youths and masters had

${ }^{127}$ Schalk, Splitting the Bill, 102-14. 
fewer reasons to engage in apprenticeships. At least in Amsterdam, on-the -job training became fraught with insecurity, making it hard to acquire skills. Eventually, vocational schools put skill formation on a more secure footing. Dutch apprenticeship only structurally revived after the Second World War, when apprenticeships and schooling became complements instead of substitutes. ${ }^{128}$

${ }^{128}$ P. Slaman, W. Marchand and R. Schalk, Kansen in het Koninkrijk: studiebeurzen 1815-2015 (Amsterdam: Boom, 2015), 144-57. 